\title{
In Memoriam: Zosia Carson
}

Zosia Carson died on 28 December 2007 following a courageous battle with cancer.

It was typical of Zosia that she first told me of her cancer over a glass of wine in Hodgson's Wine Bar in June 2006. She was upbeat from the start about her treatment and the fact that she would fight it with the support of her husband John.

Zosia's career as a law librarian was mainly with one employer. She was employed by the Legal Department of British Gas from 1989 to 2005. During her time there the company experienced major restructuring but Zosia remained in the legal department being responsible for first setting up libraries and then having to downsize. Being a "one person band" meant that Zosia quickly became a well known face at BIALL events as she networked and made contacts amongst members with similar problems. When she took voluntary redundancy in 2005 Zosia faced the daunting prospect of finding a new employer. She took various temping jobs and then started at DLA Piper on I April 2006. She was still employed there when she died.

In 1996 Zosia joined the CLIG Committee and was responsible for organising many of their events. In 1999 she joined BIALL's Membership Services Committee
(MSC) and became Chair of the Committee in 2000. During her time as Chair (2000-2003) Zosia was responsible for making changes to the Salary Survey and reducing the running costs of the committee. Discussions took place concerning academic librarians and two surveys were conducted by the Membership Services Committee - the first one to look at the relationship between BIALL and academic law librarians and the second one looking at the general state of academic law librarianship. Towards the end of her tenure on the committee a survey of Institutional Members was Zosia Carson also conducted to find out if institutional membership provided good value for money and to see if the benefits were being enjoyed by all staff working at an institutional member organisation. The results of this survey fed into the Strategic Review.

In 2004 Zosia was co-opted onto Council for one year, being elected for a two year term of office in 2005. During her membership of Council Zosia maintained her attendance at meetings despite first losing her job and then fighting her cancer. Zosia's last meeting of Council was in October 2007. At that meeting I do not think that many members realised it would be her last.

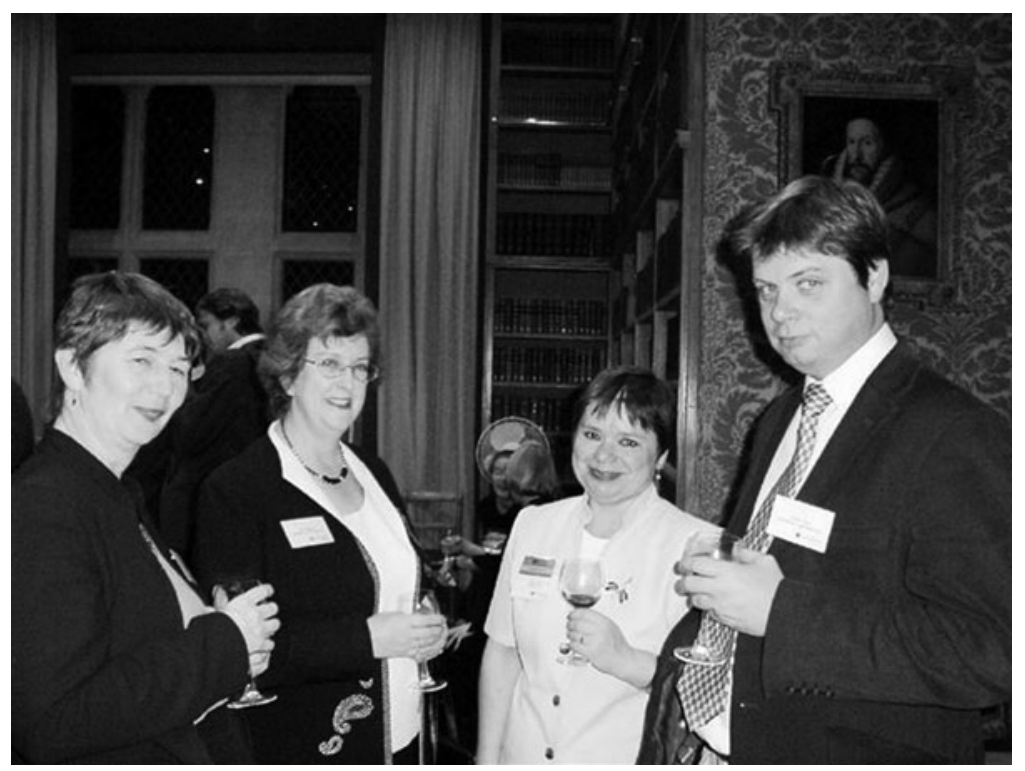

Zosia with colleagues at the Legal Awards Ceremony 2005 


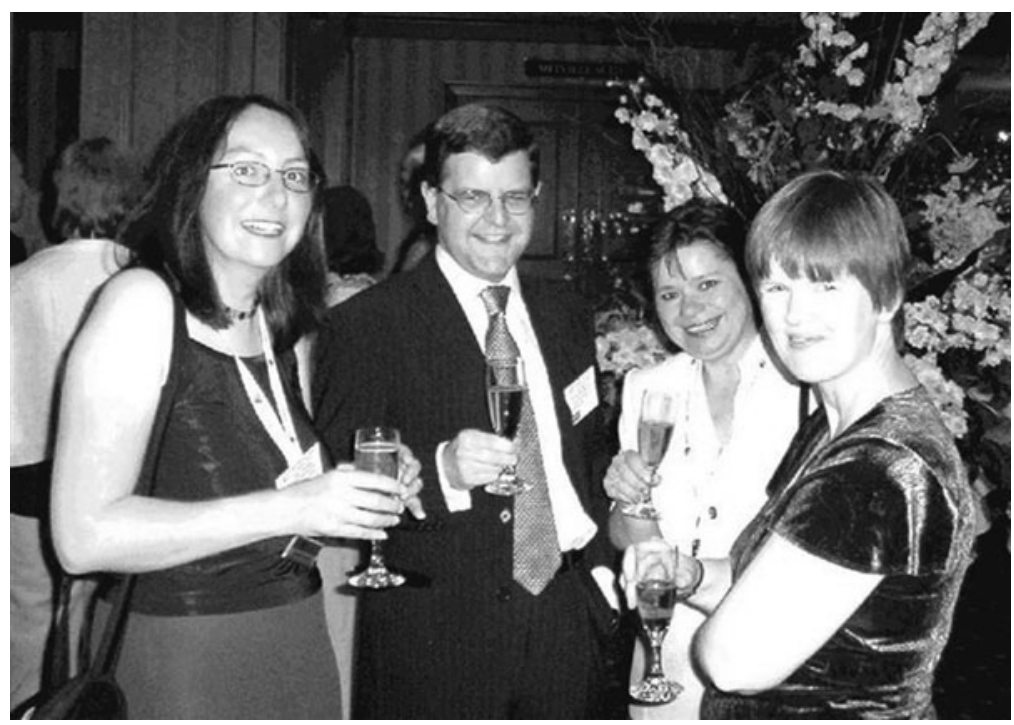

Zosia with colleagues at the BIALL Conference 2004

Zosia always said that she had been personally asked to join a committee and, as a consequence, encouraged and invited members to join MSC. As a Committee Chair she was a welcoming and inclusive person. She was a "can do" person who made people feel capable and valued. I am sure that many people would not be involved in BIALL today had it not been for her encouragement. She had a great enthusiasm and passion for BIALL which shone through in all that she did. During her time as Chair of MSC and a Council Member she was always happy to volunteer for tasks and was generous with her advice and support to others.

In September 2003 Zosia was a lucky bursary recipient to the International Association of Law Libraries Annual Conference which was held in Cape Town, South Africa. Her report from that conference can be found in Legal Information Management, 2004, 4(3), I88-193.

Cheese \& Wine Evenings and the Annual Conference will not seem the same for a while. The Cheese \& Wine Evening held in March 2007 was attended by Zosia who was in a period of remission, looking happy and showing off her new hair. It was fitting that the proceeds from the Cheese \& Wine Evening held in February 2008 were donated, in her memory, to the Princess Alice Hospice. As far as conferences are concerned various memories of Zosia come to mind - collecting masks and table decorations after a masked ball; a lively figure on the dance floor; whisky tasting in Edinburgh. Zosia was also instrumental in organising the informal meal on the evening prior to the start of the conference, where firsttimers in particular, but anyone in practice, could meet up with other conference attendees and socialise.

Outside work and BIALL Zosia had been married to John for 17 years. When I first met her, one of the things we had in common was our Yorkshire heritage and love of rugby league. Zosia's Polish heritage was also important to her. When Zosia and John moved to Staines, she told many a tale of their endeavours at self-sufficiency. One of the memories held by those at DLA Piper is the fact that she took in organic tomatoes in an attempt to improve their diet.

When the news of her death was circulated to BIALL members I was inundated by messages from members both nationally and internationally. I am sure that these messages were a great support to John. In her 2005 Council election address Zosia stated that she wanted to put back into BIALL the benefits she had gained, personally and professionally, by being involved in the activities of the Association. A true champion of BIALL, her loss will be keenly felt by all those who had the pleasure of working with her.
Catherine McArdle

Deputy Librarian

Lincoln's Inn Library 